\title{
Conventional and Mixed Model Approach to Estimate Heterosis of the Growth Traits in Boer Goat's Crossbred Offspring Populations
}

\author{
Nuzul Widyas*, Sigit Prastowo, Tristianto Nugroho and Adi Ratriyanto \\ Department of Animal Science, Faculty of Agriculture, Universitas Sebelas Maret, Surakarta, Indonesia \\ ${ }^{*}$ Corresponding author: nuzul.widyas@staff.uns.ac.id
}

\begin{abstract}
Heterosis is often utilized as a success indicator in a crossbreeding program. It is defined as the deviation of the crossbred means relative to their parental breeds. Heterosis mechanism is highly dependent on the genetic factors and thus, we incorporated genetic information in its estimation. The objective of this article was to compare heterosis estimated with conventional and mixed model approaches. In total, phenotypes of 3804 individuals were recorded. Data were obtained from a crossbreeding experiment involving Boer bucks and Jawarandu does. Observed traits were birth weight, weaning weight and average daily gain. Conventional and mixed model methods were used to estimate the heterosis. The heterosis values (\%) between $\mathrm{B} \times \mathrm{B}$ vs $\mathrm{B} \times \mathrm{J}$, estimated with conventional method were $-11.38,-10.51$ and -10.39; with mixed model were $-6.23,-9.27$ and -9.68 for BW, WW and ADG respectively. Heterosis values in $B \times(B \times J)$ relative to $B \times B$, estimated with conventional method were $-6.16,-10.35$ and -11.69 ; whereas with mixed model were $-8.01,-10.82$ and -9.14 for BW, WW and ADG respectively. Conventional method tends to underestimate the means phenotype with lower standard errors compared to mixed model analysis results in all traits. Conventional method also introduces biased heterosis estimates compared to the mixed model. Conventional method ignores any potential effects in the estimation procedures; whereas mixed model approach incorporates all the systematic and random effect including family relationship information. Thus, mixed model produced more reliable results in genetic parameters estimation. We recommend employing mixed model analysis in estimating heterosis.
\end{abstract}

Keywords: Boer goat, crossbreeding, genetic parameters, heterosis, Jawarandu goat, mixed model

Cite this as: Widyas, N., Prastowo, S., Nugroho, T., \& Ratriyanto, A. (2019). Conventional and Mixed Model Approach to Estimate Heterosis of the Growth Traits in Boer Goat's Crossbred Offspring Populations. Caraka Tani: Journal of Sustainable Agriculture, 34(1), 55-60. doi: http://dx.doi.org/10.20961/carakatani.v34i1.27620

\section{INTRODUCTION}

In a country like Indonesia, where the livestock genetic diversity is abundant (Sutarno and Setyawan, 2015) but the local species' were lacking in production aspects, attempts to optimize the available resources are necessary (Hiemstra et al., 2006; Oldenbroek, 2007). Among the programs implied by the government, crossbreeding program is currently proven to be the most promising (Widi, 2015; Agus and Widi, 2018). Crossbreeding system is widely implemented to obtain commercial stocks; where the breeder choose the desired breeds and individuals within breed through selection procedures (Bourdon, 2014). Considerations in selecting the breeds depend on the traits in breeding goal. Local breeds were mostly used as the dams for their reproductive and adaptability traits whereas exotic breeds were chosen as the male genetic resources for their productive performance.

The adoption of crossbreeding program means to introduce new genetic resources and their respective interactions which will affect

\footnotetext{
* Received for publication February 5, 2019

Accepted after corrections March 20, 2019
} 
livestock's productivity (WodzickaTomaszewska et al., 1993). Crossbreeding is able to improve livestock's productivity by utilizing the heterosis feature through the increase in heterozygosity (Hartl and Clark, 1997) which in turn, introduce new variation to the gene pool (Crow, 2001). Heterosis as a parameter contained information about the merit of the crossbred when compared to their respective purebred parent(s) and frequently utilized to assess a crossbreeding program.

Genetically, the effect of crossbreeding can be differentiated into additive and non-additive manners. The genetic basis of heterosis is very complicated; but researchers hypothesized that it is highly related with non-additive genetic effects such as dominance and epistasis which affect the interactions between alleles and/or genes (Crow, 2001; Williams et al., 2007). The effect of heterosis, however, depends on the genetic constitutions of the traits of interest. This fact is related to the number of loci involved in a trait and the differences of the allele frequencies of each locus with respect to the two parental populations.

Heterosis is normally estimated as the deviance of the crossbred relative to the purebred group (Bourdon, 2014). Since heterosis is highly genetics, the inclusion of genetic information in estimating heterosis is considered a proper thing. Komender and Hoeschele (1989) recommended mixed model analysis to be employed in the estimation of crossbreeding parameters including heterosis. In mixed model analysis all systematic and random effects were incorporated to give the estimated values. This model can also take into account the pedigree information through additive genetic relationship matrix (Henderson, 1984; Falconer and Mackay, 1996; Lynch and Walsh, 1998; Bourdon, 2014).

Currently, crossbreeding programs involving Boer and local goats are common in Indonesia. Boer goat is a meat-type African-origin goat with high growth rate and adaptable to tropical environment (Casey and van Niekerk, 1988). Whereas Jawarandu is an Indonesian local breed which is the descendant of Etawah and Kacang goats (Pandjono et al. 2014). This breed is known to be robust to humid-tropical environment and highly prolific (Wodzicka-Tomaszewska et al., 1993). The crossbreeding product between Boer bucks and Jawarandu does is potential as an improved meat-type goat breed. This research aimed to estimate and analyse the heterosis values through conventional and mixed model approaches in Boer goats pure and crossbred populations. The traits of interest in this study inclusive birth weight, weaning weight and average daily gain (ADG) traits.

\section{MATERIALS AND METHOD}

\section{Data collection}

Data was obtained from CV. Kambing Burja farm, Malang district, East Java, Indonesia. The records comprised of 3804 individuals with phenotypes and 4744 individuals in the pedigree. The individuals with phenotype records were born between 2012 to 2015. Three different populations involved: $\mathrm{B} \times \mathrm{B}$ (offspring of Boer bucks and Boer does, 461 records); $\mathrm{B} \times \mathrm{J}$ (offspring of Boer bucks and Jawarandu does, 2164 record) and $\mathrm{B} \times(\mathrm{B} \times \mathrm{J})$ which is the offspring of Boer bucks and $\mathrm{B} \times \mathrm{J}$ does (1179 records). There were three types of litter size observed (1, 2 or 3 offspring per litter). The study populations were the descendants of 26 service bucks and 1288 does. Phenotype data of birth weight (BW), weaning weight adjusted for 77 days (WW) according to the farm's management practice and average daily gain until wean $(\mathrm{ADG})$ were collected.

\section{Heterosis estimation}

The heterosis values were estimated with two different methods which were the conservative and mixed model. In the conventional approach, heterosis value was simply the differences between the means of phenotypes between pure and crossbred presented in both absolute value and relative to the purebred mean (percentage).

$$
\begin{aligned}
& H=\overline{P_{c}}-\overline{P_{p}} \\
& H \%=\frac{\left(\overline{P_{c}}-\overline{P_{p}}\right)}{\overline{P_{p}}} \times 100 \%
\end{aligned}
$$

where $\boldsymbol{H}$ was the absolute heterosis value and $\boldsymbol{H} \%$ was the relative heterosis value presented in percentage relative to the purebred phenotype means. Further, $\overline{\boldsymbol{P}_{\boldsymbol{c}}}$ was the mean phenotype value of crossbred individuals whereas $\overline{\boldsymbol{P}_{\boldsymbol{p}}}$ was the mean phenotype of the purebred.

The second heterosis estimation was performed with mixed model approach considering that this model is recommended to estimate genetic parameters inclusive the pedigree 
relationship information. The model we built was as followed:

$$
Y=X b+Z_{1} s+Z_{2} d+Z_{3} u+e
$$

where $\mathbf{Y}$ is a vector of observed variables (BW, WW, ADG), b is a vector of fixed effects including sex, birth year, litter size and breed with $\mathbf{X}$ is the design matrix corresponded to the fixed effects. There were three random effects in the model: $\mathbf{s}$ is a vector of random service bucks, $\mathbf{d}$ is random doe effect whilst $\mathbf{u}$ is random additive genetic effect where $\mathbf{u} \sim \mathrm{N}\left(\mu, A \sigma_{u}^{2}\right)$ with $\mathrm{Z}_{1}, \mathrm{Z}_{2}$ and $\mathrm{Z}_{3}$ were their respective incidence matrices (Wright, 1922; Henderson, 1984; Quaas, 2012). A vector of random residual is represented as $\mathbf{e}$ $\sim \mathrm{N}\left(0, I \sigma_{e}^{2}\right)$. The mixed model equations were solved with Restricted Maximum Likelihood (REML) methods (Kaps and Lamberson, 2004; Ott and Longnecker, 2010; Harville, 2012) using
breedR package (Munoz and Sanchez, 2018) in R programming language (R Core Team, 2015). We later derived $\widehat{P}_{p}$ and $\widehat{P}_{c}$ as the conditional means from REML solutions. Heterosis estimation employing mixed model approach was then formulated as:

$$
\begin{aligned}
H & =\widehat{P_{c}}-\widehat{P_{p}} \\
H \% & =\frac{\left(\widehat{P_{c}}-\widehat{P_{p}}\right)}{\widehat{P_{p}}} \times 100 \%
\end{aligned}
$$

\section{RESULTS AND DISCUSSION}

Purebred $(\mathrm{B} \times \mathrm{B})$ performed best compared to the two crosses in all three observed traits. However, the rank order between the two crossbreds differed between the conventional and mixed model estimates (Table 1).

Table 1. Descriptive statistics of observed traits

\begin{tabular}{lllcc}
\hline \multirow{2}{*}{ Traits } & \multirow{2}{*}{$\mathrm{Breed}$} & \multirow{2}{*}{$\mathrm{N}^{*}$} & \multicolumn{2}{c}{ Mean $\pm \mathrm{se}^{* * *}(\mathrm{Kg})$} \\
\cline { 4 - 5 } Birth weight & $\mathrm{B} \times \mathrm{B}$ & 461 & $3.20 \pm 0.03$ & $3.69 \pm 0.06$ \\
& $\mathrm{~B} \times \mathrm{J}$ & 2164 & $2.84 \pm 0.01$ & $3.46 \pm 0.05$ \\
& $\mathrm{~B} \times(\mathrm{B} \times \mathrm{J})$ & 1179 & $3.00 \pm 0.02$ & $3.38 \pm 0.06$ \\
Weaning weight & & & & \\
& $\mathrm{B} \times \mathrm{B}$ & 461 & $15.08 \pm 0.17$ & $18.01 \pm 0.26$ \\
& $\mathrm{~B} \times \mathrm{J}$ & 2164 & $13.49 \pm 0.08$ & $16.34 \pm 0.21$ \\
& $\mathrm{~B} \times(\mathrm{B} \times \mathrm{J})$ & 1179 & $13.52 \pm 0.12$ & $16.06 \pm 0.21$ \\
Average daily gain & & & & \\
& $\mathrm{B} \times \mathrm{B}$ & 461 & $0.15 \pm 0.002$ & $0.19 \pm 0.03$ \\
& $\mathrm{~B} \times \mathrm{J}$ & 2164 & $0.14 \pm 0.001$ & $0.17 \pm 0.02$ \\
& $\mathrm{~B} \times(\mathrm{B} \times \mathrm{J})$ & 1179 & $0.14 \pm 0.002$ & $0.17 \pm 0.03$ \\
\hline
\end{tabular}

Note: ${ }^{*}$ Number of observations; ${ }^{* *}$ standard error of the means

Data on Boer goat BW was around $3.20 \pm 0.03$ - $3.69 \pm 0.06$ in our study which is in agreement with previous information of $3.2 \pm 0.13$ (Browning and Leite-Browning, 2011), 3.5 \pm 0.48 (Schoeman et al., 1997) and $3.6 \pm 0.54 \mathrm{~kg}$ (Zhang et al., 2008). BW of crossbred offspring $(\mathrm{B} \times \mathrm{J})$ were $2.84 \pm 0.01$ - 3.46 \pm 0.05 ; whereas between Boer $\times$ Spanish goat, $\mathrm{BW}$ were reported to be $2.79 \pm 0.05$ (Rhone et al., 2013), $3.38 \pm 0.13 \mathrm{~kg}$ and $3.34 \pm 0.13 \mathrm{~kg}$ for crossbred kids between Boer and Kiko (Browning and Leite-Browning, 2011). Our results on Boer goats' WW were $15.08 \pm 0.17-18.01 \pm 0.26 \mathrm{~kg}$ and from previous studies were $13.50 \pm 0.62$ (Browning and Leite-Browning, 2011) and varied between $13.0 \pm 0.14$ to $16.5 \pm 0.23 \mathrm{~kg}$ (Zhang et al.,
2009). Reports from the preceding studies showed that WW for Boer $\times$ Spanish were $15.20 \pm 0.34 \mathrm{~kg}$ (Rhone et al., 2013) and 14.19 \pm 0.60 while for Boer $\times$ Kiko was $16.10 \pm 0.61 \mathrm{~kg}$ (Browning and Leite-Browning, 2011) within the range of our findings which were $13.49 \pm 0.08-16.34 \pm 0.21$.

Results of BW traits showed that in conventional methods, $\mathrm{B} \times(\mathrm{B} \times \mathrm{J})$ was superior compared to $\mathrm{B} \times \mathrm{J}$ with estimated values of $3.00 \pm 0.62$ and $2.84 \pm 0.58 \mathrm{~kg}$ respectively. Whereas in mixed model method, the BW trend was reversed; $\mathrm{B} \times \mathrm{J}$ had the higher birth weight compared to $\mathrm{B} \times(\mathrm{B} \times \mathrm{J})$ with $3.46 \pm 0.05$ versus $3.38 \pm 0.06 \mathrm{~kg}$, respectively. Similar trends were observed in WW traits. Overall, it was shown that 
conventional procedure tends to underestimate the means obtained from mixed model equations. In conventional method, the means were estimated for each breed regardless any other potential effects. On the other hand, means obtained through mixed model were corrected for systematic effects of sex, litter size and birth year (as contemporary group) as well as random effects of service bucks, random does effects and random additive genetic effects. Hence, conventional estimation results were biased (under- and/or overestimated) accompanied with lower standard errors compared to the mixed model (Komender and Hoeschele, 1989). It is proven that sex have significant effect on an animal's weight so this factor was included in the systematic part of the mixed model. Male kids grew faster and weigh heavier that female kids (van Niekerk and Casey, 1988; Zhang et al., 2009; Nugroho et al., 2018). Zhang et al. (2009) also explain that litter size was highly affecting birth weight and weaning weight.
Bigger litter size means more fetuses competing for resources and space and thus yielding in smaller individual kids at birth.

In this study, heterosis was estimated as the difference between the mean purebred phenotype and the mean of the respective crossbred. Hence, the minus (-) sign indicated that purebred means were higher than the crossbred for all traits both as absolute and percentage values (Table 2). In the comparison between $\mathrm{B} \times \mathrm{B}$ and $\mathrm{B} \times \mathrm{J}$ crossbred, heterosis values were underestimated in the conventional procedure compared to the mixed model results. However, when the $\mathrm{B} \times \mathrm{B}$ was compared against $\mathrm{B} \times(\mathrm{B} \times \mathrm{J})$, heterosis values obtained by the conventional procedure seemed to overestimate the results from mixed model. We proposed that these different trends were due to different genetic architectures of each trait and also the difference in allelic frequencies in each population (Hartl and Clark, 1997).

Table 2. The estimated heterosis values

\begin{tabular}{lcccc}
\hline \multirow{2}{*}{ Traits } & \multicolumn{2}{c}{ Conventional } & \multicolumn{2}{c}{ Mixed model } \\
\cline { 2 - 5 } & Absolute & Percentage & Absolute & Percentage \\
\hline $\mathrm{B} \times \mathrm{B}$ vs $\mathrm{B} \times \mathrm{J}^{1)}$ & & & & \\
Birth weight & -0.30 & -11.38 & -0.23 & -6.23 \\
Weaning weight & -1.58 & -10.51 & -1.67 & -9.27 \\
$\mathrm{ADG}$ & -0.02 & -10.39 & -0.02 & -9.68 \\
$\mathrm{~B} \times \mathrm{B}$ vs $\mathrm{B} \times(\mathrm{B} \times \mathrm{J})^{2)}$ & & & & \\
Birth weight & -0.20 & -6.16 & -0.31 & -8.01 \\
Weaning weight & -1.56 & -10.35 & -1.95 & -10.82 \\
ADG* & -0.02 & -11.69 & -0.02 & -9.14 \\
\hline Note: ${ }^{1)}$ heterosis between purebred and $\mathrm{B} \times \mathrm{J}$ crossbred; ${ }^{2)}$ heterosis between purebred and $\mathrm{B} \times(\mathrm{B} \times \mathrm{J})$ crossbred;
\end{tabular}

The mixed model analysis was able to correct the bias for the confounding information and thus recommended for the estimation of crossbreeding parameters (Komender and Hoeschele, 1989). Based on this statement, we will hence focus our discussions on the results obtained through mixed model analysis. When we compared $\mathrm{B} \times \mathrm{B}$ and $\mathrm{B} \times \mathrm{J}$ crossbred, crossbreeding decreased the $\mathrm{BW}$ in $\mathrm{B} \times \mathrm{B}$ by $6.27 \%$, WW by $9.27 \%$ and $\mathrm{ADG}$ by $9.68 \%$. In the comparison between $\mathrm{B} \times \mathrm{B}$ and $\mathrm{B} \times(\mathrm{B} \times \mathrm{J}), \mathrm{BW}$ of the purebred was lowered by $8.01 \%$, WW by $10.82 \%$ and ADG by $9.14 \%$.

One must recall that the genetics of a trait comprised of additive and non-additive effects (Falconer and Mackay, 1996). To be able to get the more thorough assessments, both factors should be estimated. Regardless the genetic effects, heterosis values respective to both crosses were considerably low for all traits. However, the development of $\mathrm{B} \times(\mathrm{B} \times \mathrm{J})$ crossbred require more efforts compared to $\mathrm{B} \times \mathrm{J}$ in term of time, financial and other related resources. Based on these findings only, we can postulate that $\mathrm{B} \times \mathrm{J}$ crossbred was relatively better than its counterpart $\mathrm{B} \times(\mathrm{B} \times \mathrm{J})$ crossbred.

Heterosis is a genetic phenomenon; its occurrence is very much affected especially by the non-additive genetic effects in the form of within and/or between genes interactions (Crow, 1986; Hartl and Clark, 1997; Williams et al., 2010). We can therefore explain the mechanisms of heterosis at the trait level and at the population level. The variables of interest in this study (BW, WW, ADG) were three distinct traits. Although these 
traits were moderate to highly correlated among each other, these traits were the expression of different (though some overlapped) sets of genes and thus, undergone different interactions and pathways. The effect of heterosis was also depend on the genetics of the populations in crossbreeding program. It is related to the number of genes and which genes involved in a trait. This information corresponded to the differences in allele frequencies at each locus with respect to the two purebred populations (Hartl and Clark, 1997).

\section{CONCLUSIONS}

Conventional method resulted in biased heterosis estimates compared to the mixed model approach. Conventional method ignores any potential effects; whereas mixed model approach incorporates all the systematic and random effect including family relationship information. Thus, we recommend employing mixed model analysis in estimating crossbreeding parameters including heterosis.

\section{ACKNOWLEDGEMENTS}

Authors would like to acknowledge The Indonesian Directorate General of Higher Education (DIKTI) the research grant. We would like to thank $\mathrm{Mr}$ Martinus Alexander as the managing director of CV. Kambing Burja for the cooperation and providing the data and also Hendy Darian Wirjohandodjo for sharing meaningful discussions.

\section{REFERENCES}

Agus, A., \& Widi, T. S. M. (2018). Current situation and future prospects for beef production in Indonesia - A review. Asian-Australasian Journal of Animal Sciences, 31(7), 976-983.

Bourdon, R. M. (2014). Understanding Animal Breeding (2nd ed.). Edinburgh Gate: Pearson Education Limited.

Browning, R. J., \& Leite-Browning, M. L. (2011). Birth to weaning kid traits from a complete diallel of Boer, Kiko, and Spanish meat goat breeds semi-intensively managed on humid subtropical pasture'. J. Anim. Sci, 89, 26962707. https://doi.org/10.2527/jas.2011-3865

Casey, N. H., \& van Niekerk, W. A. (1988). The boer goat. I. Origin, adaptability, performance testing, reproduction and milk production. Small Ruminant Research, 1(3), 291-302. https://doi. org/10.1016/0921-4488(88)90056-9

Crow, J. F. (1986). Basic concepts in population, quantitative, and evolutionary genetics. New York: W.H. Freeman and Company.

Crow, J. F. (2001). Heterosis. Encyclopedia of Genetics, 933. https://doi.org/10.1006/rwgn. 2001.0611

Falconer, D. S., \& Mackay, T. F. C. (1996). Introduction to Quantitative Genetics (4th ed.). Edinburgh: Prentice Hall.

Hartl, D. L., \& Clark, A. G. (1997). Principles of Population genetics (3rd ed.). Massachusetts: Sinauer Associates, Inc.

Harville, D. A. (2012). Maximum Likelihood Approaches to Variance Component and to Related Problems Estimation. Journal of the American Statistical Association, 72(358), 320338.

Henderson, C. R. (1984). Applications of Linear Models in Animal Breeding Models. Guelph.

Hiemstra, S. J., Drucker, A. G., Tvedt, M. W., Louwaars, N., Oldenbroek, J. K., Awgichew, K., ... Bhat, P. N. (2006). Exchange, Use and Conservation of Animal Genetic Resources Centre for Genetic Resources, the Netherlands $(C G N)$. Wageningen: Centre for Genetic Resources, the Netherlands (CGN).

Kaps, M., \& Lamberson, W. R. (2004). Biostatistics for animal science. (M. Kaps and W. Lamberson, Eds.). Wallingford: Cabi. https://doi.org/10.1079 /9780851998206.0000

Kinghorn, B., van der Werf, J., \& Ryan, M. (1999). Animal Breeding: Use of New Technologies. Sydney: UNiversity of Sydney.

Komender, P., \& Hoeschele, I. (1989). Use of Mixed-Model Methodology to Improve Estimation of Crossbreeding Parameters, 101113.

Lynch, M., \& Walsh, B. (1998). Genetics and Analysis of Quantitative Traits. Sunderland, MA: Sinauer Associates, Inc.

Munoz, F., \& Sanchez, L. (2018). breedR: Statistical Methods for Forest Genetic Resources Analysts. $\mathrm{R}$ package version $0.12-2$. Retrieved from https://github.com/famuvie/breedR

Nugroho, T., Nurhidayati, A., Ayuningtyas, A. I. I., Kustiyani, C., Prastowo, S., \& Widyas, N. (2018). Birth and weaning weight of kids from different Boer goat crosses. In IOP Conference 
Series: Earth and Environmental Science (Vol. 142, p. 012010). https://doi.org/10.1088/17551315/142/1/012010

Oldenbroek, J. K. (Ed.). (2007). Utilisation and conservation of farm animal genetic resources. Wageningen: Wageningen Academic Publisher. https://doi.org/10.3920/978-90-8686-592-5

Oldenbroek, K., \& Waaij, L. van der. (2015). Textbook animal breeding. Animal breeding and genetic for BSc student. Wageningen: Center for Genetic Resources and Animal Breeding and Genomics Group, Wageningen University and Reasearch Center, The Netherlands. Groen Kennisnet.

Ott, R. L., \& Longnecker, M. (2010). An Introduction to Statistical Methods and Data Analysis. Statistics (6th ed.). Belmont: Brooks/ Cole.

Pandjono, Rusman, \& Budisatria, I. G. S. (2014). Carcass Characteristics of Bligon and Kejobong Goats. In Proceedings of the 16th AAAP Animal Science Congress Vol. II 10-14 November 2014 (Vol. II, pp. 973-975). Yogyakarta: Gadjah Mada University.

Quaas, A. R. L. (2012). Computing the Diagonal Elements and Inverse of a Large Numerator Relationship Matrix the Diagonal Elements and Inverse of a Large Numerator Computing Matrix Relationship, 32(4), 949-953.

R Core Team. (2015). R: A language and environment for statistical computing. Vienna, Austria: R Foundation for Statistical Computing. Retrieved from https://www.r-project.org/

Rhone, J. A., Waldron, D. F., \& Herring, A. D. (2013). Performance of Boer-Spanish and Spanish goats in Texas I : Body weights, fertility, prolificacy, and number of kids weaned Performance of Boer-Spanish and Spanish goats in Texas I: Body weights, fertility, prolificacy, and number of kids weaned. J. Anim. Sci, 91, 4679-4683. https://doi.org/10.2527/jas20136227

Schoeman, S. J., Els, J. F., \& van Niekerk, M. M. (1997). Variance components of early growth traits in the Boer goat. Small Ruminant Research, 26(1-2), 15-20. https://doi.org/10.1016/S09214488(95)00847-0
Sutarno, \& Setyawan, A. D. (2015). Review: Genetic diversity of local and exotic cattle and their crossbreeding impact on the quality of Indonesian cattle. Biodiversitas, 16(2), 327-354. https://doi.org/10.13057/biodiv/d160230

van Niekerk, W. A., \& Casey, N. H. (1988). The Boer goat. II. Growth, nutrient requirements, carcass, and meat quality. Small Ruminant Research, 1, 355-368.

Waaij, K. O. en L. van der. (2014). Animal Breeding and Genetics for BSc Student. Netherland: Wegeningen University and Research Centre.

Widi, T. S. M. (2015). Mapping the impact of crossbreeding in smallholder cattle systems in Indonesia. Wageningen University and Research Centre. Retrieved from http://edepot.wur.nl/ 345219

Williams, J. L., Aguilar, I., Rekaya, R., \& Bertrand, J. K. (2010). Estimation of breed and heterosis effects for growth and carcass traits in cattle using published crossbreeding studies. Journal of Animal Science, 88(2), 460-466. https:// doi.org/10.2527/jas.2008-1628

Williams, R. B. H., Chan, E. K. F., Cowley, M. J., \& Little, P. F. R. (2007). The influence of genetic variation on gene expression, 17, 1707-1716. https://doi.org/10.1101/gr.6981507.specific

Wodzicka-Tomaszewska, M., Djajanegara, A., Gardiner, S., Wiradarya, T. R., \& Mastika, I. M. (1993). Small Ruminant Production in the Humid Tropics. Surakarta: Sebelas Maret University Press.

Wright, S. (1922). Coefficients of Inbreeding and Relationship. The American Naturalist, 56(645), 330-338.

Zhang, Chun-yan, Zhang, Y., Xu, D., Li, X., Su, J., \& Yang, L. (2009). Genetic and phenotypic parameter estimates for growth traits in Boer goat. Livestock Science, 124(1-3), 66-71. https://doi.org/10.1016/j.livsci.2008.12.010

Zhang, Chunyan, Yang, L., \& Shen, Z. (2008). Variance components and genetic parameters for weight and size at birth in the Boer goat. Livestock Science, 115(1), 73-79. https://doi.org/ 10.1016/j.livsci.2007.06.008 